\title{
AMERICA'S OBJECTIONS TO THE INTERNATIONAL CRIMINAL COURT
}

\author{
Eric D. Smaw ${ }^{1}$, University of Kentucky
}

\begin{abstract}
$\underline{\text { Abstract }}$
In what follows, I present a combination of philosophical and political perspectives on human rights and the establishment of an international criminal court. I present the United States' pragmatic objections to establishing an international criminal court. Contrary to the United States' pragmatic objections, I argue in favor of an international criminal court. Ultimately, I attempt to illustrate that the international criminal court will have protective measures designed to prevent political abuses of justice. When working properly, these protective measures will satisfy the U.S.'s pragmatic concerns. Thus, I conclude, the U.S. ought not abandon its longer history of supporting the establishment of an international criminal court.
\end{abstract}

\section{Introduction}

Nearly fifty years after the international criminal tribunals at Tokyo and Nuremberg, members of the 1998 Diplomatic Conference at Rome voted on a treaty to establish a permanent international criminal tribunal to adjudicate the most egregious violations of human rights. Until this time, international criminal tribunals were ad hoc and the status of human rights was uncertain. While a permanent interna tional criminal tribunal has been established, human rights are still vehemently debated but the trend seems to be moving towards universalism. This is evidenced by the plethora of international conventions articulating international human rights aspirations, the 1998

\footnotetext{
${ }^{1}$ Eric D. Smaw is a Ph.D. candidate in the Department of Philosophy at the University of Kentucky.
} 
Rome proposal for establishing an international criminal tribunal, and the increasing willingness of the international community to punish perpetrators of genocide and piracy.

In what follows, I present a combination of philosophical and political perspectives on human rights and the establishment of an international criminal court. I present the United States' pragmatic objections to establishing an international criminal court. Contrary to the United States' pragmatic objections, I argue in favor of an international criminal court. Ultimately, I attempt to illustrate that the international criminal court will have protective measures designed to prevent political abuses of justice. When working properly, these protective measures will satisfy the U.S.'s pragmatic concerns. Thus, I conclude, the U.S. ought not abandon its longer history of supporting the establishment of an international criminal court.

\section{The Philosophy of Human Rights: Universal or Cultural?}

International legal theory inherited its conception of human rights as civil, political, social, and/or economic entitlements granted to humans or groups of humans, against which no government, sovereign State, or people may infringe without due process of law from the tradition of social and political philosophy during the age of enlightenment. ${ }^{2}$ Though identifiable discussions of human rights can be found in the various social and political philosophical traditions since antiquity ${ }^{3}$, the idea of human

\footnotetext{
${ }^{2}$ Definition mine. This definition is a combination of $17^{\text {th }}$ century thru $19^{\text {th }}$ century philosophical ideals concerning individual rights. See Berlin, Isaiah, Two Concepts of Liberty (Oxford: Clarendon Press, 1958), Locke, John, Second Treatise of Government (Indianapolis: Hackett Pub., 1980), Jean-Jacques Rousseau's The Social Contract and Discourses (New York: E.P. Dutton, 1950), Mill, John S., Utilitarianism (New York: Macmillan Pub., 1957), Marx, Karl, and Fredrick Engels, The Communist Manifesto (New York: New York Labor New Co., 1948), and Marx, Karl, The Economic and Philosophic Manuscripts of 1844 Martin Milligan trans., Dirk Struik ed. (Moscow: Foreign Language Publishing House, 1961).

${ }^{3}$ For various discussions of human rights prior to enlightenment philosophy see Sophocles's Antigone (New York: Washington Square Press, 1970), Plato's “The Laws” in The Dialogues of Plato $4^{\text {th }}$ ed.
} 
rights as entitlements to negative and positive liberties began with the enlightenment philosophers. ${ }^{4}$ According to enlightenment social and political philosophy, human rights are either natural insofar as they emanate from God, nature, or reason, or positivistic insofar as they are granted by the state.

John Locke, in the Second Treatise of Government, articulates a conception of human rights as natural. According to Locke, humans naturally exist in a state of perfect freedom and liberty in which they harmoniously cooperate with one another. God wisely endowed humans with the faculty of reason for the purposes of attaining the laws of nature. ${ }^{5}$ On this view, rights to life, liberty, and property are to be found in the universal laws of nature. ${ }^{6}$ They are therefore natural universal human rights. ${ }^{7}$ Notice that this conception of human rights has the virtue of reconciling possible tensions between religious fundamentalism, on the one hand, and enlightenment utopianism, on the other. Locke accomplishes this by way of a two-track argument. First, he wisely acknowledges the infinite wisdom of God in endowing humans with reason, and then he allows for the

(Oxford: Clarendon Press, 1953), Aristotle's "Politics" in The Complete Works of Aristotle (Princeton: Princeton U.P., 1984), and St. Thomas Aquinas's Summa Theologica Lib. II, Pt. II. The Fathers of the English Dominican Province trans. (New York: Benziger, 1947).

${ }^{4}$ Berlin, Isaiah, Two Concepts of Liberty (Oxford: Clarendon Press, 1958). For enlightenment philosophical discussions of human rights see John Locke's Second Treatise of Government (Indianapolis: Hackett Pub., 1980), Thomas Hobbes's Leviathan (Oxford: Basil Blackwell, 1957), and Jean-Jacques Rousseau's The Social Contract and Discourses (New York: E.P. Dutton, 1950).

${ }^{5}$ Locke, John, Second Treatise of Government (Indianapolis: Hackett Pub., 1980), pp. 10-11.

${ }^{6} \mathrm{My}$ terminology (the use of the term man) is not mean to be exclusive. Here I am using man inclusively, meaning men and women.

${ }^{7}$ Contemporary interpretations of enlightenment thought on human rights are that such rights were universal. However, many enlightenment philosophers do not extend their conceptions of human rights to Africans, South Americans, North Americans (prior to the discovery), and women. See Lauren, Paul G., Power and Prejudice: The Politics and Diplomacy of Racial Discrimination 2ed. (Boulder: Westview Pub., 1988) pp. 32-50. 
infinite capacities of reason in its ability to uncover human rights in the laws of nature. ${ }^{8}$ This is a classic natural law conception of universal human rights.

In contrast, Marx rejects the natural law conception of human rights as "idealistic and ahistorical." 9 For Marx, rights are distinctly historical and cultural. ${ }^{10}$ Concepts such as law, rights, justice, democracy, and so on, are categories whose contents are determined by the material and economic conditions of particular societies. Because these categories are historically determined, their contents change as the material and economic conditions of society change.

In order to determine the content of human rights Neo-Marxists conduct analysis on two distinct levels: a social level and a natural level. As Neo-Marxists explain it, the creative capacities of humans serve at least to two distinct purposes. On the one hand, humans create or reproduce the means of their subsistence and, on the other hand, they create themselves or to become fully human through actualizing their natural potentials. These are fundamental theses of Marxism. When considered together, these theses provide the grounds for determining the content of Neo-Marxist human rights.

According to Neo-Marxists, society ought to facilitate the realization of human potential; but in order to do this, fundamental social and economic needs must first be satisfied. These social and economic needs determine the content of human rights.

\footnotetext{
${ }^{8}$ The $17^{\text {th }}$ century enlightenment period is generally understood as the time when reason "comes of age," and diverges from religion. From the period of enlightenment on, reason and religion are generally contentiously juxtaposed.

${ }^{9}$ Marx, Karl, The Economic and Philosophic Manuscripts of 1844, Martin Milligan trans., Dirk Struik ed. (Moscow: Foreign Language Publishing House, 1961).

${ }^{10}$ Marx, Karl, and Fredrick Engels, The Communist Manifesto (New York: New York Labor New Co., 1948). This conception of human rights begins with the manifesto. Also see Marx, Karl, The Economic and Philosophic Manuscripts of 1844 Martin Milligan trans., Dirk Struik ed. (Moscow: Foreign Language Publishing House, 1961), and Karl Marx's On The Jewish Question trans. Jack Jacobs (New York: New York University Press, 1992).
} 
Notice that the differences in the Neo-Marxist conception of human nature leads one to articulate rights that are fundamentally different from those articulated by John Locke. John Locke's human rights are universal and civil and political in nature, while the Neo-Marxist human rights are culturally relative and social and economic in nature. But also notice that both of these conceptions of human rights are susceptible to the objection that so-called human rights will differ from theorist to theorist, depending on one's conception of human nature. The point of such an objection is to raise doubt about the possibility of identifying universal human rights. I will return to this objection shortly. For now, it should suffice to say that the point of such an objection is to undermine the possibility of identifying universal human rights.

\section{Gone Universal: The Politics of Human Rights}

While philosophizing about international human rights began as early as the seventeenth century, the work of establishing and enforcing international human rights law did not begin until the mid-nineteenth century, and even then, the standards that ultimately withstood scrutiny were fairly uncontroversial. For example, under the Geneva Convention of 1864 warring states were obligated to allow humanitarian aid (primarily medical assistance) to wounded, sick, or captured soldiers, and in the 1920's an International Labor Organization was created in order to develop and supervise labor regulations designed to protect workers. These obligations represent the extent of international humanitarian law at the turn of the century but none of them were overly controversial. ${ }^{11}$ The lag-time between philosophizing about human rights and establishing international human rights law resulted from an unyielding assumption about

\footnotetext{
${ }^{11}$ Forsythe, David, Human Rights in International Relations (Cambridge: Cambridge U.P., 2000) p. 24.
} 
absolute state sovereignty over citizens. ${ }^{12}$ While states were willing "to sign general statements of principle,"13 they resisted efforts to "interfere with what they... regarded as sovereign jurisdiction." 14 But the atrocities of WWII would change this way of thinking forever.

Nazi Germany's systematic extermination and relocation of millions of Jewish people, forced heretofore- unconcerned world leaders to articulate, guarantee, and protect universal human rights irrespective of citizenship, religion, or ethnicity. The international tribunals at Nuremberg and Tokyo were particularly successful at facilitating this process for they articulated hitherto ignored crimes against international comity. ${ }^{15}$ In this sense the Nuremberg and Tokyo tribunals established a precedent that would forever shatter the assumption of absolute state sovereignty over citizens. More importantly, however, they gave rise to the questions of codifying international crimes and establishing a permanent international court in which to prosecute such crimes. Unfortunately, however, the promise and practice of protecting universal human rights rarely coincided. Since the Tokyo and Nuremberg there have been numerous violations of universal human rights but only two international criminal tribunals: The tribunal in Yugoslavia in 1991 and the tribunal in Arusha for the Rwandan genocides of $1994 .^{16}$ Today, the problems of impunity, judicial inefficiency, and the lack of international procedural standards are among the foremost justifications for a permanent international

\footnotetext{
12 Ibid., p. 17. See Forsythe's discussion of the Westphilian system.

${ }^{13}$ Lauren, Paul G., Power and Prejudice: The Politics and Diplomacy of Racial Discrimination 2 ed. (Boulder: Westview Pub., 1988) p. 28.

${ }^{14}$ Ibid., p. 28.

15 www.ichr.org/icc/pap3sec2.htm "Crimes Within the ICC's Jurisdiction and Essential Elements of Their Definitions" International Criminal Court Briefing Series volume 1, number 3.

${ }^{16}$ The following sites identify violation of human rights that have gone unpunished: www.OASCastillo/chapterV.cub.html, www.usdos.lybia.htm, also see David Forsythe's Human Rights in International Relations (Cambridge: Cambridge U.P., 2000).
} 
tribunal. Nevertheless, as we shall see, a permanent international court is not without problems.

\section{In Practice: International Law, International Human Rights, and the International Criminal Court}

In 1998 the Lawyer's Committee for Human Rights proposed eight fundamental

principles that would ensure that a permanent criminal court operates independently,

fairly, efficiently, and effectively:

(1) The Principle of Universal Jurisdiction: the court should have jurisdiction over genocide, war crimes, and crimes against humanity, for such crimes are exceptionally egregious and of particular concern to the international community as a whole.

(2) The Principle of Automatic Jurisdiction: The court should have automatic jurisdiction over genocide, war crimes, and crimes against humanity.

(3) The Ex Officio Proceedings Principle: The prosecutor should be able to initiate proceedings ex officio.

(4) The Principle of Non-Interference: The international criminal court should be able to proceed without the involvement of the Security Council.

(5) Due Process: The International Criminal Court should ensure the highest standards of fair trial and due process.

(6) The Protection Principle: The international criminal court should ensure the protection of women, children, victims, and witnesses.

(7) The Compliance Principle: All states should cooperate and comply with the International Criminal Court.

(8) And The Principle of Independent Finance: And the international court should be financed out of the regular U.N. budget. That is, independently of States. ${ }^{17}$

More importantly, however, the Lawyer's Committee offered the following four justifications for a permanent international court: (1) an ICC would efficiently address

offenses of universal human rights and provide relief for the victims of such offenses, (2) an ICC would counter judicial systems that are unable or unwilling to enforce international criminal laws, (3) an ICC would provide a remedy to the limitations of ad

${ }^{17}$ www.lchr.org/icc/princ.htm 
hoc tribunals, and (4) an ICC would provide a central enforcement mechanism for international criminal law. ${ }^{18}$

Since the Lawyer Committee's work, members of the international community attended a Diplomatic Conference at Rome and voted to approve a treaty to establish a permanent international criminal court with automatic universal jurisdiction over war crimes, genocide, and crimes against humanity. According to the treaty, the international criminal court will be complementary to national judicial systems, acting only when states are unwilling or unable to enforce international criminal law. The court will consist of a Presidency, an Appeals Division, a Trial Division, a Pre-Trial Division, an Office of the Prosecutor, a Registry, and eighteen elected judges. Of the 160 states represented at the convention, 120 voted in favor of the treaty, 26 of which have already signed it. Among the 26 signatures were Italy, Norway, Belgium, Canada, France, Greece, the Netherlands, Switzerland, Germany, and Spain. ${ }^{19}$ Twenty-one of those who attended the convention abstained from the vote and only seven states voted against the treaty. Among them were the US, China, Iraq, Libya, Yemen, Israel, and the Sudan. ${ }^{20}$ As of April $12^{\text {th }}$ the treaty establishing the ICC went into effect after the 60th State ratified it.

\section{Beyond Rome}

Since Rome, there has been vehement opposition to establishing an international criminal court, most notably from the U.S. In "The International Criminal Court vs. The American People," Lee Casey and David Rivkin, Jr. articulated the U.S.'s pragmatic

\footnotetext{
${ }_{18}^{18}$ www.lchr.org/icc/paplintro.htm

19 www.ichr.org/icc/papv2n1.htm.

20 www.ichr.org/icc/papv2nl.htm.
} 
objections to establishing an international criminal court. According to Casey and Rivkin, since the crimes over with the ICC will have jurisdiction are vaguely defined, governments that are hostile to the U.S. could use the terminologically vague language against U.S. peacekeepers and military personnel, subjecting them to unwarranted criminal indictment. ${ }^{21}$ Even worse, once indicted under the ICC, U.S. citizens would face criminal proceedings that are foreign and contrary to the core principles of the U.S. constitution, ${ }^{22}$ in particular, Article III, section 2 of the U.S. Constitution and the VI Amendment. ${ }^{23} 24$ Moreover, "in an astonishing break with the norms of international law, the Rome treaty extends the ICC's jurisdiction to the citizens of countries that have not signed and ratified the treaty." 25 This means, in effect, that the ICC will have the authority to judge the acts of U.S. officials.

\section{In Response}

There are three objections to the ICC that deserve a response: Casey and Rivkin's objections that (1) crimes under the ICC's jurisdiction could be used against U.S. peacekeepers and military personnel, (2) the objection that the ICC would subject U.S. citizens to foreign criminal proceedings that are contrary to the principles of the U.S. constitution, and (3) the objection that the ICC's jurisdiction over non-signatories represents a break with commonly practiced international law.

\footnotetext{
${ }^{21}$ Casey, Lee A., and David B. Rivkin, Jr. "The International Criminal Court vs. The American People" in Backgrounder (Washington: The Heritage Foundation, Feb. 5, 1999) no. 1249. p. 1.

22 Ibid., pp. 1-3.

${ }^{23}$ Ibid., p. 3. For an articulation of these principles see Constitutional Law: Civil Liberty and Individual $\underline{\text { Rights }} 3^{\text {rd }}$ ed. William Cohen and David J. Danelski ed. (New York: The Foundation Press, 1994) pp. 1110-1113.

${ }^{24}$ Ibid., p. 3. Also see p. 1113 (Amendment V of the Bill of Rights) of Constitutional Law: Civil Liberty and Individual Rights $3^{\text {rd }}$ ed. William Cohen and David J. Danelski ed. (New York: The Foundation Press, 1994)

25 Ibid., pp. 1-2.
} 
Casey and Rivkin object to the ICC on the grounds that the crimes over which the ICC will have jurisdiction are defined using vague terminology, therefore countries that are hostile to the U.S. could use the terminologically vague language against U.S. peacekeepers and military personnel, subjecting them to unwarranted and unfair criminal indictments and convictions. While this is a legitimate concern, it is certainly not one that should prevent the U.S. from supporting the establishment of an international criminal court. The Rome treaty articulates at least five safeguards to prevent politically motivated prosecutions: First, the ICC's jurisdiction is limited to crimes against humanity, war crimes, and genocide. Criminal proceeding regarding such crimes must be authorized by states in order to proceed. This represents the highest standard of pre-trial scrutiny, one in which the U.S. was instrumental in defining. Secondly, the ICC is a complementary court, acting only when national judiciaries are unwilling or unable to enforce international criminal law. This would allow the U.S. to investigate accusations against its citizens. If the U.S. investigates an accusation and finds that prosecution is unwarranted, then ICC cannot intercede. Third, the ICC will have a pre-trial division, responsible for scrutinizing accusations brought before the court. Even if an unwarranted accusation passes pre-trial scrutiny, the Security Council can delay a trial up to one year, giving the country of the accused time to investigate the accusation. Fourth, the judges elected to the ICC are to be highly respectable and of impeccable credentials. And finally, there are procedures for removing ICC officials who engage in politically motivated investigations. ${ }^{26}$ When working properly, these five safeguards would prevent politically motivated prosecutions.

\footnotetext{
${ }^{26}$ www.un.org/law/icc.
} 
Casey and Rivkin also object to the ICC on the grounds that it would subject U.S. citizens to foreign criminal proceedings that are contrary to the U.S. constitution. But there is nothing novel about U.S. citizens facing foreign criminal proceedings that are contrary to the principles of the U.S. constitution. The case of Michael Fay v. Singapore (1994) in which a U.S. citizen living in Singapore was found guilty of vandalism and sentence to caning, and the case of Her Majesty the Queen v. Jones (1997) in which a U.S. citizen was found guilty of various immigration violations and jailed beyond his sentence illustrate that U.S. citizens sometimes face foreign criminal proceeding that are contrary to the principles of the U.S. constitution. In fact, the U.S.'s policy for case in which a U.S. citizen feels that he has been subjected to an unfair judicial proceeding in another country is first to have the U.S. citizen exhaust the remedies for redress in the foreign country. The U.S. will step in only if there has been a gross denial of justice.

Finally, Casey and Rivkin's objection that the ICC's jurisdiction over citizens of non-signatories is contrary to commonly practiced international law is false. The Vienna Convention on the law of treaties has a provision for holding states accountable to peremptory norms of international law. In fact, the Geneva Conventions of 1949 articulates such peremptory norms, obliging states to prosecute anyone guilty of violating their provisions against war crimes, irrespective of whether, or not, the accused is a citizen of a state that has ratified the conventions. Moreover, the U.S. has utilized customary international law as a way of prosecuting violations of important treaties. In the United States v. Yunis, the U.S. prosecuted a Lebanese citizen for hijacking a Jordanian airliner despite the fact that Lebanon has not ratified the 1970 Hague Hijacking 
Convention. ${ }^{27}$ And, in 1998, the U.S. prosecuted a Palestinian citizen for hijacking an Egyptian airliner despite that fact that Palestine has not ratified the 1970 Hague Hijacking Convention. ${ }^{28}$ Again, in 1992, the U.S. prosecuted a Canadian for violating the convention on the Status of Refugees, despite the fact that Canada had not ratified that convention. There are many other examples in which states prosecuted foreigners under conventions to which their states are not signatories.

\section{In The Final Analysis}

In my final analysis I wish to underscore two principles that require the U.S. to support the ICC. First, the principle of consistency requires the U.S. to endorse the ICC. The U.S. has a long history of supporting international criminal tribunals: U.S. judges and attorneys played key roles in the Nuremberg, Tokyo, and Rwandan tribunals. In fact, the U.S. had been supporting the establishment of the ICC until the provision giving the U.N. Security Council the power to veto cases remanded for adjudication was rejected. Because the U.S. has a long history of supporting international criminal tribunals, has participated in prosecuting others in international criminal tribunals, and had been supporting the establishment of a permanent ICC, consistency requires the U.S. to ratify the Rome Treaty.

Secondly, the principle of international legitimacy requires the U.S. to support the ICC. Although the Nuremberg and Tokyo trials were criticized for applying victor's justice and ex post facto laws to the losers of WWII, they were nevertheless seen as fundamentally legitimate because they had the endorsement of the international community and because Germany and Japan had grossly violated international comity.

\footnotetext{
${ }^{27}$ www.britannicaindia.com/eb/nic.

28 www.britannicaindia.com/ed/nic. See United States v. Ali Rezaq. 1998.
} 
Currently, the U.S. is facing criticism from members of the international community concerning its detainment of Afghanistan war "detainees" at Guantanomo Bay. Such criticisms would be curtained if the Guantanomo Bay detainees were turned over to an international criminal tribunal. Moreover, turning the Afghanistan war "detainees" over to an international criminal tribunal would further legitimize the U.S.'s case against them.

\section{Conclusion}

In this project, I have presented the philosophical and political perspectives on universal human rights and the international criminal court. I have also presented the U.S.'s pragmatic objections to the idea of an international criminal court. I have presented some responses to the U.S.'s objections to the ICC and reasons why the U.S. ought to support the establishment of an ICC. I have concluded that the U.S. ought to support the establishment of an international criminal court. 


\section{Bibliography}

Aquinas, Thomas, St. Summa Theologica. Lib. II, Pt. II. The Fathers of the English Dominican Province trans. (New York: Benziger, 1947).

Aristotle's "Politics" in The Complete Works of Aristotle (Princeton: Princeton U.P., 1984).

Austin, John. "The Province of Juris Prudence Determined." Reading in the Philosophy of Law. (New York: Broadview, 1999).

Berlin, Isaiah. Two Concepts of Liberty. (Oxford: Clarendon Press, 1958).

Brandt, Richard. "Towards a Credible Form of Utilitarianism.” Moral Philosophy. $2^{\text {nd }}$ ed. Trans. George Sher. (Fort Worth: Harcourt Brace, 1996).

Casey, Lee A., and David B. Rivkin, Jr. "The International Criminal Court vs. The American People." Backgrounder. (Washington: The Heritage Foundation, Feb. 5, 1999). no. 1249.

Constitutional Law: Civil Liberty and Individual Rights $3^{\text {rd }}$ ed. William Cohen and David J. Danelski ed. (New York: The Foundation Press, 1994).

Finnis, John. Natural Law and Natural Rights. (Oxford: Clarendon Press, 1980).

Forsythe, David. Human Rights in International Relations. (Cambridge: Cambridge U.P., 2000).

Hart, H.L.A. "The Nature of International Law." Reading in the Philosophy of Law. (New York: Broadview, 1999).

Locke, John. Second Treatise of Government (Indianapolis: Hackett Pub., 1980).

Lauren, Paul G. Power and Prejud ice: The Politics and Diplomacy of Racial Discrimination 2ed. (Boulder: Westview Pub., 1988).

Marx, Karl, and Fredrick Engels, The Communist Manifesto. (New York: New York Labor New Co., 1948).

Marx, Karl, The Economic and Philosophic Manuscripts of 1844 Martin Milligan trans., Dirk Struik ed. (Moscow: Foreign Language Publishing House, 1961).

Marx, Karl. On The Jewish Question trans. Jack Jacobs (New York: New York University Press, 1992).

Mill, John S., Utilitarianism. (New York: Macmillan Pub., 1957). 
Perry, Michael J. “Are Human Rights Universal? The Relativist Challenge and Related Matters.” Human Rights Quarterly. 19.3 (1997).

Plato. "The Laws." The Dialogues of Plato. $4^{\text {th }}$ ed. (Oxford: Clarendon Press, 1953).

Rousseau, Jean-Jacque. The Social Contract and Discourses. (New York: E.P. Dutton, 1950).

Slomanson, William, R. ed. Fundamental Perspectives on International Law. (San Diego: Wadworth Pub., 2000).

Sophocles. Antigone. (New York: Washington Square Press, 1970).

Zakaria, Fareed. "Culture is Destiny: A Conversation with Lee Kuan Yew." Foreign Affiars. March-April (1994). vol. 73, number 2. 
Eric D. Smaw

\section{Websites Cited}

www.ichr.org/icc/pap3sec2.htm.

www.ichr.org/icc/pap1intro.htm.

www.OAS-Castillo/chapterv.cub.html.

www.usdos.lybia.html.

www.ichr.org/icc/papv2n1.htm.

Www.ichr.org/icc/papv2nl.htm.

www.lchr.org/icc/princ.htm.

www.lchr.org/icc/pap1intro.htm

www.un.org/law/icc.

www.britannicaindia.com/eb/nic.

www.britannicaindia.com/ed/nic. 
Eric D. Smaw

\section{Court Cases Cited}

Her Majesty The Queen v. Jones (1997)

Ins. v. Doughty (1992)

Singapore v. Fay (1994)

United States v. Yunis (1997)

United States v. Ali Rezaq. (1998) 